International

Medical Society

http://imedicalsociety.org

\title{
Health Problems of Institutionalized Elderly \\ OBRIIINAL
}

Sérgio Augusto Silva Paredes Moreira1, Jordana Almeida Nogueira², Luípa Michele Silva ${ }^{3}$, Luiz Fernando Rangel Tura ${ }^{4}$, Tatyanni Peixoto Rodrigues ${ }^{5}$, Maria do Socorro Costa Feitosa Alves ${ }^{6}$, Maria do Céu Pinto Marques ${ }^{7}$, Karoline Lima Alves ${ }^{8}$, Laysa Bianca Gomes de Lima ${ }^{9}$, Antonia Oliveira Silva ${ }^{10}$

\section{Abstract}

Introduction: Human aging is marked by a decrease in the performance of some daily tasks, some even considered banal and imperceptibly when this limitation is followed by chronic diseases, the elderly becomes a source of concern for the family.

Objective: Identifying the health problems of the elderly living in long-stay institutions from self-reported diseases. This is a descriptive and quantitative study, conducted in northeastern Brazil capital, involving 138 elderly. For data collection we used a questionnaire containing demographic variables, institutional and related to self-reported health problems. Data were evaluated using bivariate analysis and association chi-square.

Results: Predominance of women was found (61.6\%), aged 60-69 years old (39.1\%), coming from the state capital (51.4\%), and institutional permanence time between 1-5 years (77.5\%). The most frequent diseases were related to the cardiovascular system (15.9\%) and endocrine, nutritional and metabolic diseases (9.4\%). It showed a significant association between self-reported diseases and the age of the elderly $(p=0.047)$.

Conclusion: It is expected to raise awareness among health professionals to provide a better assistance to the institutionalized elderly focusing on the real needs of these persons.

\section{Introduction}

In Brazilian society it is noticeable that the elderly with good health and that do not represent financial concerns for the family, since they too often help at home to care for the grandchildren and with fi-
1 Master's Student, Federal University of Paraíba, João Pessoa (PB), * .

2 PhD, Associate Professor, Federal University of Paraíba, João Pessoa (PB), *

3 Doctor, researcher for the Federal University of Paraíba, João Pessoa (PB), *

4 PhD, Professor Associate, Federal University of Rio de Janeiro, Rio de Janeiro (RJ), *.

5 Doctoral Student, Federal University of Paraíba, João Pessoa (PB), * , Scholarship Holder of the Higher Education Personnel Improvement Coordination (CAPES), *

6 PhD, Chief Professor, Federal University of Rio Grande do Norte, Natal (RN), *

7 Professor Associate, University of Évora, Évora (PT), Portugal.

8 Master's Student, Federal University of Paraíba, João Pessoa (PB), *

9 Nurse, researcher for the Federal University of Paraíba, João Pessoa (PB), *

10 PhD, Chief Professor, Federal University of Paraíba, João Pessoa (PB),

*: Brazil.

\section{Contact information:}

Luipa Michele Silva.

झ" luipams@gmail.com

\section{Keywords}

Elderly; Institution of Long Stay for the Aged; Health of Institutionalized Elderly. 
nancial aid. Furthermore, they are good consumers. However, when affected by chronic illnesses or become dependent, this view changes, because the care they need come to require drug spending, caregivers, hospitalizations, health plans and differentiated food. The old begins to become a source of concern and a "nuisance" for family [1].

Human aging is marked by a decrease in the performance of some daily tasks, some even considered banal and seamlessly, they are becoming increasingly difficult to be performed, only being perceived dependence, when someone else helps you make them, for example, to feed themselves. Nowadays the family is no longer so willing to take care of their elders. Among the factors that create this difficulty can highlight women entering the labor market and the existing capitalist model, which impacts the Brazilian families, and the financial difficulties impose a family restructuring, which can create obstacles for the maintenance of elderly in their own homes [1-2].

Unable to pay a caregiver and not be a familiar available for this performance, the family seeks asylum as a solution to the elderly in need of care. The idea is that asylum is a care environment, recreation and socialization among seniors. For them it is a generative attitude of negative feelings, because it is expected that children or other family members are responsible for their loved aging process [2-3].

The institutionalization is not yet a common practice in our society, but social, economic, demographic and health factors have encouraged this practice. Finally, changes in family structures also reduce the prospect of growing old in a family environment $[4,5]$.

Contrary to some families who see in institutionalizing the resolution of the problem, researchers warn of the importance of maintaining the elderly in family and community life, in order to maintain citizenship, dignity and autonomy of these individuals. Not only is the family the fundamental factor for institutionalization, but the lack of financial resources leads many older people to be forwarded to the institutions subsidized by the government or charities $[5,6]$.

Age in a long term care facility has been challenging for the elderly, society and government, as these places should offer suitable conditions for life extension. When an elderly person loses his life referential, until its health status is changed, becoming more vulnerable to illness. In the elderly has been common the involvement of depression, a medical condition that is associated with decreased quality of life, dissatisfaction with life, making it difficult to perform daily activities and may lead to risk of suicide [6].

Faced with the progressive increase in the institutionalization, studies aimed at addressing the maintenance and improvement of health and living conditions of the elderly in these contexts become important to be investigated considering the relevance: social and political to be investigated. In this sense one may question: What are the health problems identified from the self-reported diseases for seniors living in long-stay institutions? Therefore, this study aims to identify the health problems of the elderly living in long-stay institutions from selfreported diseases by considering an issue of relevant political, social and economic factor and involving government, the community, the services health near these institutions and the media.

\section{Method}

Descriptive study with a quantitative approach, performed with elderly people living in long-stay institutions (ILP) in the city of João Pessoa, Paraíba/ Brazil. The study population consisted of 420 elderly two ILPS. To determine the sample size, it adopted a ratio of $11 \%$, considering the percentage of the resident elderly population in the municipality (DATASUS 2012), estimation error not exceeding 5\% and a confidence level of $95 \%$ in the sample. Precaution to a potential loss of $10 \%$ determined that 138 elderly were investigated.

Regarding the characteristics of these institutions, 
we opted for the non-probabilistic selection of the elderly considering the following inclusion criteria: present age equal to or over 60, have cognitive conditions to answer to the instrument and accept the invitation to participate. For data collection it designed a questionnaire consisting of information about gender, age, length of stay in the institution, perceived morbidity, use of assistive technologies and the merits of the elderly to be institutionalized. To facilitate understanding of the types of selfreported health problems, they were categorized according to the International Classification of Diseases (ICD-10) [7].

Data collection took place between May and July 2010, seniors who agreed to participate in the interviews signed a free and informed consent, based on the Resolution 196/96 of the National Health Council (CNS) [8]. This study was approved by the Research Ethics Committee in the area of local health under number 261/09, FR: 294027 and authorized by the heads of the ILPS.

Data were tabulated in Microsoft Excel $2010 \AA$ program and the statistical processing was with SPSS $19.0 \AA$ program. The results were presented in the form of simple percentage frequency tables and inferential statistics was performed with the chi-square test is deemed significant around the lower result than 0.05 .

\section{Results}

The analysis of demographic and institutional variables (Table 1), there was predominance of female participation (61.6\%), aged between 60 and 69 years old $(39.1 \%)$, coming from the state capital (51.4\%), and time institutional remain between 1 and 5 years $(77.5 \%)$. The presence of some sort of health problem was reported by $42 \%$ of the elderly. On the use of assistive technology $13.0 \%$ reported their use.

Regarding the association between the occurrence of self-reported health problems and characteristics of the institutionalized elderly, it became
Table 1.Distribution of the elderly respondents according to some features of institutionalization. João Pessoa/PB, 2013.

\begin{tabular}{|l|c|c|}
\hline \multicolumn{1}{|c|}{ Variables } & $\mathbf{n}$ & $\%$ \\
\hline Gender & & \\
\hline Male & 53 & 38.4 \\
\hline Female & 85 & 61.6 \\
\hline Age (in years) & & \\
\hline 60 - 69 & 54 & 39.1 \\
\hline 70 - 79 & 42 & 30.4 \\
\hline + than 80 & 42 & 30.4 \\
\hline Time in the institution (in years) & & \\
\hline 1 - 5 & 107 & 77.5 \\
\hline 6 - 10 & 17 & 12.3 \\
\hline + than 10 & 14 & 10.1 \\
\hline Presence of illnesses & & \\
\hline Presence & 58 & 42.0 \\
\hline Absence & 80 & 58.0 \\
\hline Use of Assistive Technologies & & \\
\hline Yes & 18 & 13.0 \\
\hline No & 120 & 87.0 \\
\hline Origin & & \\
\hline João Pessoa & 71 & 51.4 \\
\hline Countryside of Paraíba & 55 & 39.9 \\
\hline Another State & 12 & 8.7 \\
\hline Total & 138 & 100 \\
\hline
\end{tabular}

clear the similarity of proportions and the lack of association between variables. However, a tendency to presence or absence of self-reported health problems of elderly people with 6-10 years of institutionalization was observed. (Table 2)

In relation to self-reported health problems, 74 events were mentioned. For analysis, it was decided to group them according to the International Classification of Diseases and Related Problems/ICD-10 [6]. The most frequent diseases were those related to the cardiovascular system (15.9\%), followed by endocrine, nutritional and metabolic diseases $(9.4 \%)$, diseases of the musculoskeletal system and connective tissue (5.1\%) and mental and behavio- 
Table 2. Association between the presence or absence of self-reported health problems, according to the characteristics of the elderly living in long-stay institution in the city of João Pessoa/PB.

\begin{tabular}{|c|c|c|c|c|c|c|c|}
\hline \multirow{3}{*}{ Variables } & \multicolumn{4}{|c|}{ Health problems } & \multirow{2}{*}{\multicolumn{2}{|c|}{ Total }} & \multirow{3}{*}{ P* } \\
\hline & \multicolumn{2}{|c|}{ Presence } & \multicolumn{2}{|c|}{ Absence } & & & \\
\hline & $n$ & $\%$ & $n$ & $\%$ & $n$ & $\%$ & \\
\hline \multicolumn{8}{|c|}{ Age (in years) } \\
\hline $60-69-$ & 26 & 48.1 & 28 & 51.9 & 54 & 100.0 & \multirow{3}{*}{0.210} \\
\hline $70-79-$ & 13 & 31.0 & 29 & 69.0 & 42 & 100.0 & \\
\hline+ than 80 & 19 & 45.2 & 23 & 54.8 & 42 & 100.0 & \\
\hline \multicolumn{8}{|l|}{ Gender } \\
\hline Male & 24 & 45.3 & 29 & 54.7 & 53 & 100.0 & \multirow{2}{*}{0.332} \\
\hline Female & 34 & 40.0 & 51 & 60.0 & 85 & 100.0 & \\
\hline \multicolumn{8}{|c|}{ Time in the institution (in years) } \\
\hline $1-5$ & 47 & 43.9 & 60 & 56.1 & 107 & 100.0 & \multirow{3}{*}{0.067} \\
\hline $6-10$ & 9 & 52.9 & 8 & 47.1 & 17 & 100.0 & \\
\hline+ than 10 & 2 & 14.3 & 12 & 85.7 & 14 & 100.0 & \\
\hline
\end{tabular}

ral disorders (3.6\%). About $58.0 \%$ of respondents mentioned not presenting some kind of disease (Table 3). The analysis of the association between selfreported types of diseases and age was significant $(p=0.047)$.

\section{Discussion}

As expected, there was a higher frequency of females between the institutionalized elderly, 85 (61.6\%). The literature suggests that women live longer than men; this has been explained by lower exposure to certain risk factors at work, lower prevalence of smoking and alcohol intake. In addition, differences are highlighted as the attitude towards disease and disability and the influence of increased coverage of the gynecological and obstetric care $[2,4,9]$.

Other authors attribute the greater institutionalization of women, because of older women represent the major portion of this population [1]. And another possible explanation is that they are the

Table 3. Association between self-refered diseases by elderly people interviewed grouped according to the international classification of diseases (CID-10), and age. João Pessoa/PB, 2013.

\begin{tabular}{|c|c|c|c|c|c|c|c|c|c|}
\hline \multirow{3}{*}{$\begin{array}{c}\text { CID } 10 \\
\text { (System/Apparatus diseases) }\end{array}$} & \multicolumn{6}{|c|}{ Age } & \multirow{2}{*}{\multicolumn{2}{|c|}{ Total }} & \multirow{3}{*}{ P* } \\
\hline & \multicolumn{2}{|c|}{$60-69$} & \multicolumn{2}{|c|}{$70-79$} & \multicolumn{2}{|c|}{+ than 80} & & & \\
\hline & $n$ & $\%$ & $n$ & $\%$ & $\mathrm{n}$ & $\%$ & $\mathrm{n}$ & $\%$ & \\
\hline \multicolumn{10}{|l|}{ Age (in years) } \\
\hline Cardiovascular & 10 & 7.2 & 5 & 3.6 & 7 & 5.1 & 22 & 15.9 & \multirow{11}{*}{0.047} \\
\hline Endocrine and metabolic & 10 & 7.2 & 1 & 0.7 & 2 & 1.4 & 13 & 9.4 & \\
\hline Musculoskeletal and connective tissue & 2 & 1.4 & 4 & 2.9 & 1 & 0.7 & 7 & 5.1 & \\
\hline Mental and behavioral disorders & 1 & 0.7 & 1 & 0.7 & 3 & 2.2 & 5 & 3.6 & \\
\hline Rheumatism & - & - & - & - & 2 & 1.4 & 2 & 1.4 & \\
\hline Eyes and attachments & 1 & 0.7 & - & - & - & - & 1 & 0.7 & \\
\hline Genitourinary & 2 & 1.4 & - & - & 1 & 0.7 & 3 & 2.2 & \\
\hline Respiratory & - & 0 & 2 & 1.4 & 1 & 0.7 & 3 & 2.2 & \\
\hline Nervous system & - & 0 & 2 & 1.4 & 1 & 0.7 & 3 & 2.2 & \\
\hline Has no health problem & 28 & 20.3 & 29 & 21.0 & 23 & 16.7 & 80 & 58.0 & \\
\hline Total & 54 & 39.1 & 42 & 30.4 & 42 & 30.4 & 138 & 100 & \\
\hline
\end{tabular}


providers of informal care, but cannot have one to care for them. Often for not having someone take responsibility for their care, women get older is more exposed to the typical weaknesses of older and in this case the institutionalization becomes the only alternative [10].

Differing from other reported results [9-11], the early form came institutionalization, ie found to occur in younger elderly, in the range of 60 to 69 years old of $39.1 \%$, a result similar to that found in Londrina, where the average age was 66.5 years old [12]. According to the IBGE the proportion of seniors aged 65 and over increased from 5.1\% in 1991 to $5.8 \%$ in 2000 and $7.2 \%$ in 2010 and the share of deaths of the population of 70 years of age or older in Paraiba is of $48.8 \%$ [13].

What is seen are seniors aging in these institutions are subject to a time of institutionalization between one to five years (77.5\%) as well as in other Brazilian study [14]. The search for an ILP is due to several factors, but mainly by the lack of support from family members in the care binomial/assistance to that old or the option of the elderly, due to external factors such as loneliness, urban violence, family exclusion and the possibility of being cared for by a team [11, 15].

The problem of an institutionalization without the consent of the elderly, a fact that was observed during the field work through reports that they do not receive visits from their families and social neglect. This kind of situation creates vulnerability, increase in diseases linked to the immune system, depression, anxiety and suicidal thoughts [14-16].

In all studies of institutionalized elderly were found some kind of health problem. However, it is important to note that this fact can be explained by the elderly's health condition institutionalized in general is more weakened those living in the community. Chronic diseases cause long-term problems with walking, vision and hearing and among the participants of this research was discreet use of assistive devices for these problems. Two Brazilian studies have assessed the use of devices that support the march in institutionalized elderly. The frequency of use of these devices varied between $14.8 \%$ and $61.7 \%[10,14]$. This study found a ratio of $13.0 \%$ who used this feature.

The role of assistive technologies is to enable the functional independence of older people who use and ease in performing daily activities. Its use may be secured, as a support during locomotion, or have an opposite effect, contributing to an unsafe mobility and the possibility of falls, where space does not permit proper utilization or use of which is not prescribed [17].

Regardless of sex and age no significant interference in the presence or absence of health problems, the institutionalization time yes, can interfere with the health-disease-care process. A longitudinal study in Brazil was able to prove that the time of institutionalization generates a high incidence of disability. Brazilian law provides that health-related issues or social assistance lead to institutionalization of any old guy. Therefore, functional disability can be considered one of the main reasons for the large number of newly institutionalized elderly and long-term can lead to deaths due to complications of healths conditions generated by this dependence [18].

When associated with diseases classified in ICD10 and age group, there was a statistical significance. Study in Maceió [19] with elderly living in the community, aged 60 and 69, also found no such association. According to the National Health Survey, a study of national scope, the self-reported prevalence of hypertension in adult Brazilian population in 2013 was approximately 31.3 million individuals across the country [20].

Seniors reported an average of 1.3 conditions, a lower result than that found in another study [4], where it was found, on average, 2.1 references to diseases. So, as in other studies, diseases of the circulatory system were the most frequently mentioned by participants, followed by endocrine, nutritional and metabolic diseases, in addition to diseases of the musculoskeletal system and connective tissue $[4,5,10,11]$. They are chronic diseases that require 
prolonged care assistance and sometimes costly. In addition, the occurrence of complications can modify the level of dependence and quality of life of these subjects, which is worrying because some of these institutions are philanthropic and do not provide the necessary care for the elderly they met.

Studies show that the presence of chronic diseases interfere with the quality of life for seniors, and are directly related to functional disability, and this compromises the independence and autonomy in daily activities, which may explain his hospitalization in ILP $[16,17]$.

As a result of chronic diseases, older people use multiple medications, requiring multidisciplinary care and laboratory tests. But not always these institutions can provide the necessary treatment, since they are financed with funds from the various government levels or retirement/pensions of the elderly [21].

In this study it was shown that institutionalization is early, early in retirement, contrast with the literature in which the trend of increased chance of institutionalization occurs with advancing age [9-11]. Every decade the risk of decreased functional capacity folds, and there is significant increase in chronic diseases and the incidence of hospital admissions. These reasons have enhanced the likelihood of institutionalization of that group [22].

The results on the institutionalization of the elderly are consistent with the literature $[9,10,14]$ and bring a reminder of the importance of social participation of the elderly in maintaining their wellbeing, signaling that social isolation and loneliness in old age may be related to the decline in physical and mental health, and subsequent institutionalization. One of the alternatives, so this does not happen, you have someone to accompany him in daily activities and close social relationships, as neighbors and community groups because it can be a strategy to promote their self-esteem and autonomy.

Another factor that interferes with functional decline in the elderly is physical inactivity, which in addition to slow the functional decline in old age helps to reduce the onset of chronic diseases. Thus, the need is evident in the creation of an appropriate infrastructure for the development of activities favorable to active aging within these institutions [22]. Such measures entail psychosocial and economic benefits not only the elderly and society in general.

In this sense, nurses and healthcare staff who work with the elderly need to know the complex aging process of those who are under the care of ILPS and prevalent pathologies in this context. You should be aware of in order to identify them and thereby determine appropriate actions to confront and overcome these problems.

\section{Conclusion}

This study shows the health problems identified in the elderly living in long-stay institutions from self diseases referred to in the findings showed that most residents are female aged between 60 and 69 years old and resided there for a period of 1 and five years. Diseases of the circulatory system were the most frequent, followed by endocrine, nutritional and metabolic diseases; diseases of the musculoskeletal system and connective tissue and mental and behavior disorders.

The elderly with chronic diseases are vulnerable and need care to prevent disability to achieve faster. Studies like this show the reality of institutionalized elderly and tend to raise awareness among health professionals, especially nurses to promote care for the portion of the population under consideration.

The study presents as limit the fact that it focused only self-reported diseases to describe health problems, since not had records to search diagnoses established by health professionals.

\section{References}

1. Rabelo LC, Chianca TCM. Perfil epidemiológico, clínico e de independência funcional de uma população idosa institucionalizada. Rev. bras. enferm. 2012; 65(3): 482-88. doi: 10.1590/S0034-71672012000300013 
2. Finnegan S, Bruce J, Lamb SE, Griffiths F. Predictors of attendance to group exercise: a cohort study of older adults in long-term care facilities. BMC geriatrics. 2015; 15(1):1-12. doi:10.1186/ s12877-015-0043-y

3. Santana AJ, Barboza FJC. Prevalência de sintomas depressivos em idosos institucionalizados na cidade do Salvador. Rev. Baiana Saúde Pública. 2007; 31, (1): 134-46. Disponível em: http:// inseer.ibict.br/rbsp/index.php/rbsp/article/viewFile/1400/1037. Acesso em: agosto de 2015

4. Gautério DP, Santos SSC, Pelzer MT, Edaiane Joana Barros; Larissa Baumgarten. The characterization of elderly medication users living in long-term care facilities. Rev. esc. enferm. USP. 2012; 46(6): 1394-1399. doi: 10.1590/S0080-62342012000600016

5. Leite MT, Battisti IDE, Berlezi EM, Scheuer AI. Idosos residentes no meio urbano e sua rede de suporte familiar e social. Texto contexto - enferm. 2008; 17(2): 250-57. doi: 0.1590/S010407072008000200005

6. Freire FS, Mendonça LH, Costa AJB. Sustentabilidade econômica das instituições de longa permanência para idosos. Saúde em Debate. 2012; 36(95): 533-43. doi: 10.1590/S010311042012000400005

7. Cesar CLG, Laurenti R, Buchala CM, Figueiredo GM, Carvalho WO de Caratin CV. de S. Uso da Classificação Internacional de Doenças em inquéritos de saúde. Rev. bras. epidemiol. 2001; 4(2): 120-29. doi: 10.1590/S1415-790X2001000200007

8. Ministério da Saúde (BR). Conselho Nacional de Saúde, Comissão Nacional de Ética em Pesquisa. Resolução Nº 196 de 10 de outubro de 1996: diretrizes e normas regulamentadoras de pesquisa envolvendo seres humanos. Brasília (DF): MS; 1996. Disponível em: http://bvsms.saude.gov.br/bvs/saudelegis/cns/1996/ res0196 1010 1996.html. Acesso em: setembro de 2015

9. Del Duca GF, Silva SG da Thumé E, Santos IS, Hallal PC. Indicadores da institucionalização de idosos: estudo de casos e controles. Rev. Saúde Pública. 2012; 46(1): 147-53. doi: 10.1590/ S0034-89102012000100018

10. Alencar MA, Bruck NNS, Pereira BC, Câmara TMM, Almeida RDS. Perfil dos idosos residentes em uma instituição de longa permanência. Rev. bras. geriatr. gerontol. 2012; 15(4): 785-96. Disponível em: http://www.scielo.br/pdf/rbgg/v15n4/17.pdf. Acesso em: agosto de 2015

11. Silva ER, Sousa ARP, Ferreira LB, Peixoto HM. Prevalence and factors associated with depression among institutionalized elderly individuals: nursing care support. Rev. esc. enferm. USP. 2012; 46(6): 1387-93. doi: 10.1590/S0080-62342012000600015

12. Mesas AE, Andrade SM, Cabrera MAS, Bueno VLRC. Salud oral y déficit nutricional en adultos mayores no institucionalizados en Londrina, Paraná, Brasil. Rev. bras. epidemiol. 2010; 13(3):43445. doi: 10.1590/\$1415-790X2010000300007

13. Instituto Brasileiro de Geografia e Estatística. (BR). Censo demográfico. Rio de Janeiro: Instituto Brasileiro de Geografia e Estatística; 2010. Disponível em: http://www.ibge.gov.br/home/ estatistica/populacao/censo2010/default resultados amostra. shtm. Acesso em: agosto de 2015.
14. Menezes RL, Bachion MM Souza JT, Nakatani AYK. Estudo longitudinal dos aspectos multidimensionais da saúde de idosos institucionalizados. Rev. bras. geriatr. gerontol. 2011; 14(3): 485-96. Disponível em: http://www.scielo.br/pdf/rbgg/v14n3/ v14n3a09. Acesso em: setembro de 2015.

15. Eika M, Espnes GA, Hvalvik S. Nursing staff's actions during older residents' transition into long-term care facility in a nursing home in rural Norway. International Journal of Qualitative Studies on Health and Well-being. 2014; 9:10. doi: 10.3402/ qhw.v9.24105

16. Wongpakaran T, Wongpakaran N. Detection of suicide among the elderly in a long term care facility. Clinical Interventions in Aging. 2013; 8:1553-9. doi: 10.2147/CIA.S53355

17. Schonnop R, Yang $Y$, Feldman F, Robinson E, Loughin $M$, Robinovitch SN. Prevalence of and factors associated with head impact during falls in older adults in long-term care. CMAJ: Canadian Medical Association Journal. 2013; 185(17):E803-10. doi: $10.1503 / \mathrm{cmaj} .130498$

18. Mattos IE, do Carmo CN, Santiago LM, Luz LL. Factors associated with functional incapacity in elders living in long stay institutions in Brazil: a cross-sectional study. BMC Geriatrics. 2014; 14:47. doi: 10.1186/1471-2318-14-47

19. MB, Ribeiro. Dados sociodemográficos e condições de saúde de idosas inscritas no PSF de Maceió, AL. Rev. bras. geriatr. gerontol. 2011; 14(4): 613-24. doi: 10.1590/\$1809-98232011000400002

20. Andrade SSA, Stopa SR, Brito AS, Chueri PS, Szwarcwald CL, Malta DC. Prevalência de hipertensão arterial autorreferida na população brasileira: análise da Pesquisa Nacional de Saúde, 2013. Epidemiol. Serv. Saúde. 2015 June; 24(2): 297-04. doi: 10.5123/S1679-49742015000200012

21. Acurcio FDA, Lourenço $A$, Silva $A Q R$, Rocha NP, Silvelra MR, Klein $\mathrm{CH}$, Rozenfeld $\mathrm{S}$. Complexidade do regime terapêutico prescrito para idosos. Rev Assoc Med Bras. 2009; 55(4): 468-74. doi: 10.1590/S0104-42302009000400025

22. Oliveira ERA, Gomes MJ, Paiva KM. Institucionalização e qualidade de vida de idosos da região metropolitana de Vitória - ES. Esc. Anna Nery Rev Enferm. 2011; 15(3): 618-23. doi: $10.1590 /$ S1414-81452011000300011 